\title{
The Effect of Corporate Financial Pressure on Financial Statement Fraud during the COVID-19 Pandemic
}

\author{
Wahyu Manuhara Putra ${ }^{1 *}$
}

\author{
${ }^{1}$ Department of Accounting, Faculty of Economics, Universitas Muhammadiyah Yogyakarta, Indonesia \\ *Corresponding author. Email: wahyu_m@umy.ac.id
}

\begin{abstract}
This study aims to test the accuracy of the financial statement fraud model in companies before and during the COVID-19 pandemic. It is assumed that companies will commit financial statement fraud due to economic pressure during the COVID-19 pandemic by analyzing various factors in predicting financial statement fraud. The factors affecting financial statement fraud during the COVID-19 pandemic are financial pressures, which consist of financial stability pressures, financial target pressures, and external financial pressures. This research data used secondary data derived from annual reports of companies listed on the Indonesia Stock Exchange during 2020. This study employed the purposive sampling method and utilized multiple linear regression analysis tools through SPSS version 25 software. Analysis of data testing in this study used assumption test classic form of normality test, multicollinearity test, autocorrelation test, and heteroscedasticity test. Besides, hypothesis testing used T-test, F-test, and determinant coefficient. The model testing results indicate that the financial stability pressure variable had the most significant positive effect on financial statement fraud.
\end{abstract}

Keywords: financial statement fraud, financial stability pressures, financial target pressures, external financial pressures

\section{BACKGROUND}

The COVID-19 pandemic has had a serious impact on all countries. In the economic sector, the growth experiences slowing or stagnant. All economic activities, trades, and online transactions also stopped. It resulted in the absence of income from economic activities. If there is no appropriate government policy solution for this pandemic, the worst impact will be the reoccurrence of the monetary crisis for Indonesia, as was in the 1997-1998 crisis.

Moreover, the business world and industry are worried that the COVID-19 pandemic crisis will impact the financial statements for 2020 and beyond due to the increasingly unclear end of the handling of COVID-19. The performance of financial statements will also definitely be significantly affected, especially because the company's income has decreased due to the weakening of people's purchasing power and the possibility of inflation [1].

Companies whose performance targets are only based on finances will certainly experience large deviations from their performance achievements. To overcome this, companies might try to keep their financial statements in a stable state by trying as hard as possible to create financial reports that look good [2]. Thus, it opens up opportunities for industries and companies to commit financial statement fraud during this pandemic.

Financial fraud or corruption has a dangerous impact in various countries, including Indonesia. The development of financial fraud is also increasing [3]. It was stated [4] that in the United States, financial fraud causes enormous losses in almost all industries. As happened in 2002, a fraud scandal was carried out by ENRON with Arthur Andersen Public Accounting Firm. Likewise, the WorldCom, PharMor, and Crazy Eddie scandals manipulated financial statements [5]. In Indonesia, several companies also committed fraudulent acts, such as Batavia Air, PT. Waskita Karya, PT. Lancung Sempurna, and PT. Kimia Farma [6]. The research results of the Association of Certified Fraud Examiners have proven that $58 \%$ of cases of fraud reports were carried out at the managerial level, $36 \%$ were carried out by managers without involving other people, and $6 \%$ were carried out by managers through collusion with employees [3]. Therefore, the actual perpetrators of fraud can be at all managerial levels. Furthermore, the study results found that $83 \%$ of fraud was actually carried out by company owners, while crimes whose perpetrators were management received evidence of more than 50\% [7].

In addition, financial fraud in companies occurs because they are always required to make improvements in their performance. Good company performance will increase the company's value so that the company's stock price will be high. However, if the company's performance declines so that its profits fall, the management will tend to commit fraud so that its performance remains good. It is done by manipulating or increasing profits that are not as they should be.

On the other hand, the company's main goal is to improve performance, which is reflected in the performance of the company's financial statements. The purpose of a 
company's financial statements is to provide information about an entity's financial position, financial performance, and cash flows, which is useful to most report users in making economic decisions. The financial statements also reflect the results of the management's performance and accountability to the company owners and the broader community. Nevertheless, with the increase in cases of financial fraud scandals globally, various parties assume that management has committed fraud in financial statements [8].

There are several models in explaining the factors that influence financial fraud. The Fraud Triangle Model explains that fraud is influenced by pressure, opportunity, and rationalization. This pandemic period also has more or less affected financial statement fraud, as stated [9] that the COVID-19 pandemic provides the perfect set of circumstances for the Fraud Triangle - opportunity, motivation, and rationalization. Research findings [10] revealed that the economic crisis would lead to an increase in the likelihood of financial fraud, at around $80 \%$. By looking at the current economic crisis caused by the COVID-19 crisis, it is also possible to increase the possibility of financial fraud.

Amir Ghandar, in charge of reporting and assurance at Chartered Accountants Australia and New Zealand, emphasized that in the Fraud Triangle in the COVID-19 reporting environment, there will be enormous pressure on management to be able to maintain performance and meet requirements as well as satisfy the market and perform on a par with the industry. It is supported by research [2], which proves that fraud in financial statements during a pandemic will be more vulnerable to occur in the realm of pressure. For this reason, this research, which is set during a pandemic, focuses on the realm of pressure to see if there is a company's financial statement fraud. It was also highlighted [11] that it will be the biggest stress factor felt by companies and employees during a recession and economic instability. Financially distressed companies also face pressure to cheat their finances to meet revenue targets or secure financing.

Several studies have observed the pressure perspective on the Fraud Triangle, which can be identified into three variables: financial stability, external pressure, and financial targets. It was carried out in prior research [12]. The same thing was also done in previous studies [13] [14]. From the description above, this research is intended to detect financial statement fraud by analyzing the pressure factor according to the support of research results and expert findings. This study also examines whether the pressure factors affect financial fraud. This research was conducted to detect financial statement fraud based on a map of Indonesia's characteristics during the COVID-19 pandemic, which is still rarely conducted in Indonesia. For this reason, the problem formulations in this study are as follows: (1) Does financial stability affect financial statement fraud during the COVID-19 pandemic? Does financial target affect financial statement fraud during the COVID-19 pandemic? Does external pressure affect financial statement fraud in the time of the COVID-19 pandemic?

\section{LITERATURE REVIEW}

\subsection{Financial Statement Fraud Concept}

Financial statement fraud is intentional or negligent in reporting financial statements that are presented not in accordance with generally accepted accounting principles. According to Wells (2014), financial statement fraud includes several modes, including (a) falsification, alteration, or manipulation of financial records, supporting documents, or business transactions; (b) intentional omission of significant events, transactions, accounts, or other information as a source of financial statement presentation; (c) intentional misapplication of accounting principles, policies, and procedures used to measure, recognize, report, and disclose economic events and business transactions; (d) intentional omission of information that should be presented and disclosed regarding the accounting principles and policies used in preparing the financial statements.

The motivation for someone to commit fraud is relatively diverse. One theory that explains a person's motivation to commit fraud is the Fraud Triangle Theory based on research results [15]. This concept is also called Cressey's Theory since this term emerged because of research conducted by Donald R. Cressey in 1953. Cressey's research was published under the title Other's People Money: A Study in the Social Psychology of Embezzlement. Cressey's research generally explains the reasons why people commit fraud. There are three elements of the Fraud Triangle, including opportunity, rationalization, and pressure.

According to [16], pressure can be categorized into four groups: (a) financial pressures, (b) vices pressures, and (c) work-related pressures and other pressures. In the first part, almost $95 \%$ of frauds are committed due to financial pressure. According to [16], financial pressures related to fraud benefit the perpetrators, including the greedy nature of a lifestyle beyond ordinary people, large debt bills, and urgent needs. Furthermore, it was asserted [17] that financial pressure is the most common type of fraud. In the company, the mode of financial fraud is to increase the value of assets in the statement of financial position and net income in the statement of comprehensive income. Here, management has pressure to commit fraud because of an unfavorable cash position, bad debts, loss of customers, 
obsolete inventory, market declines, or breached loan covenant restrictions.

Pressure is also a factor that comes from individual conditions that cause someone to commit fraud. Pressure from within a person can be influenced by the work environment. One of the environmental factors that can cause pressure on an employee is organizational justice in the company. Justice is related to how a person gets a reward in the form of salary or other compensation for his work (distributive justice) and how the procedure relates to that reward (procedural justice).

The second part of the pressure factor is vices pressures caused by the urge to fulfill bad habits, such as gambling, drugs, alcohol, and expensive negative items. As another example, someone who likes to gamble will be compelled to do anything to earn money as a bet (gambling). Then, the third part is related to work (work-related pressures), in this case, the absence of job satisfaction obtained by employees, for instance, lack of attention from management, injustice, etc. They can make employees have to commit fraud to get "rewards" for their hard work.

\subsection{Hypothesis}

\subsubsection{The Effect of Financial Stability on Financial} Statement Fraud

When a company is in a stable condition, the company's value will increase in the eyes of investors, creditors, and the public. [18] and [19] show that in cases where the company experiences growth below the industry average, management will manipulate financial statements to improve the company's prospects. The company tries to improve its good outlook, one of which is by manipulating the information on the wealth of its assets. The form of manipulation of financial statements carried out by management is related to the growth of company assets [8]. The study results [20] revealed that the financial stability variable, which was proxied by the ratio of changes in total assets, is proven to affect financial statement fraud. Research conducted [8] also confirmed that the greater the ratio of changes in the total assets of a company, the higher the probability of committing fraud in the company's financial statements. In another research [12], financial stability had a positive effect on financial statement fraud. Research [21] also verified that financial stability had a significant positive effect on the possibility of earnings manipulation. These results are consistent with the findings [22], which found that financial stability affected financial statement fraud. Likewise, the results [23] uncovered that financial stability affected financial statement fraud. In a crisis environment due to the COVID-19 pandemic, research [2] authenticated that the financial stability variable had a positive and significant impact on financial statement fraud. Based on this description, the following research hypothesis was proposed:

H1: Financial stability has a positive effect on financial statement fraud.

\subsubsection{The Effect of Financial Targets on Financial Statement Fraud}

According to SAS No. 99 (AICPA, 2002), financial targets are excessive pressure on management to obtain financial targets that have been set at the beginning of the period by the board of directors and/or management. The financial target is one measure of the pressure factor that uses the ROA proxy. ROA is the result of profit after tax in the previous year divided by total assets in the previous year.

Managers are often under pressure to prove to the principal that they can manage and control assets properly so that the profits received by the company can increase. In addition to profits that will increase, managers also get reciprocity in the form of bonuses that will increase. Thus, management will strive to achieve the targets set in various ways, one of which is by committing fraud in the financial statements. The higher the company's financial target, the more vulnerable the management is to the tendency of financial statement fraud, where one of the forms is by manipulating earnings.

Research conducted [24] demonstrated that financial targets positively affected the tendency of financial statement fraud. High financial targets in the previous year indicate high company profitability and make the company's profit target obtained in the following year also high. However, a study [20] affirmed the opposite that financial targets did not affect the tendency of financial statement fraud. It means that the size of the financial level targeted by the company did not affect management to commit fraudulent tendencies in financial statements. The increase in ROA is also not a pressure for management since the increase in ROA is in line with the increase in the operational quality of employees. Besides, research [12] revealed that financial targets had a positive effect on financial statement fraud. Other studies [13] [14] also showed that financial targets affected financial statement fraud. Based on this description, the hypothesis used to test it is:

$\mathrm{H} 2$ : Financial targets have a positive effect on the tendency of financial statement fraud.

\subsubsection{The Effect of External Pressure on Financial Statement Fraud}

Companies often experience pressure from external parties. One of the pressures often experienced by company management is the need to obtain additional debt or external sources of financing to remain competitive, including research financing and development or capital expenditures [8]. External financing needs are related to cash generated 
from debt, which was proxied by the leverage ratio in this study.

A study [20] ascertained that the external pressure variable, proxied by the leverage ratio, affected financial statement fraud. Another research [25] also showed that the external pressure variable as measured by the leverage ratio affected financial statement fraud. A study [26] also found that external pressure had a positive effect on financial statement fraud. Consistent results were also obtained [12] for a study that external pressure positively affected financial statement fraud. Also, research [13] stated that external pressure affected financial statement fraud. A study [26] also uncovered that external pressure had a positive effect on financial statement fraud. Based on this description, the following research hypothesis was put forward:

$\mathrm{H} 2$ : External pressure has a positive effect on financial statement fraud.

\section{RESEARCH METHOD}

The population in this study was manufacturing companies in Indonesia listed on the Indonesia Stock Exchange in 2019 - 2020 as many as 83 companies. The sampling method used in this research was the purposive sampling method. The criteria used in this sampling included (1) manufacturing companies listed on the Indonesian Stock Exchange for the period 2019-2020; (2) companies that published annual financial reports on the company website or the IDX website during the 2019-2020 period; (3) companies that were not delisted from the IDX during the study period. The type of data used in this study was secondary data, namely the company's annual financial report data.

\subsection{Variable Operational Definition}

\subsubsection{Dependent Variable}

The measurement of financial statement fraud in this study was proxied by earnings management. It was explained [27] that earnings management is related to changes in financial statements that aim to mislead stakeholders on organizational performance or influence the results of contracts based on accounting numbers in financial statements. Thus, management's earnings management is carried out by choosing accounting methods to manipulate company profits or control accrual transactions. According to [28], discretionary accrual is a method to reduce earnings reports by manipulating accounting policies that are difficult to detect. Therefore, earnings management was measured by discretionary accruals. The measurement of discretionary accruals then used working capital accruals. The calculation is as follows:

Earnings management $=$ Working capital accruals $(\mathrm{t})$ : Sales period $(\mathrm{t})$

Accrual of working capital $=\mathrm{AL}-\mathrm{HL}-\mathrm{Cash}$

$\mathrm{AL}=$ Change in current assets in period $\mathrm{t}$
$\mathrm{HL}=$ Change in current liabilities in period $\mathrm{t}$

Cash $=$ Change in cash and cash equivalents in period $\mathrm{t}$

\subsubsection{Independent Variables}

Financial stability, proxied by ACHANGE $=($ Total Assets $\mathrm{t}$ - Total Assets t-1): Total Assets t-1

Financial target, proxied by ROA = Profit after tax: Total Assets

External pressure, proxied by the leverage ratio $(\mathrm{LEV})=$ Liability: Total Asset

\subsection{Data Analysis}

\subsubsection{Classic Assumption Test}

The classical assumption test aims to determine the feasibility of the regression model. It is also intended to ensure that the regression model does not contain multicollinearity and heteroscedasticity and the resulting data are normally distributed.

\subsubsection{Hypothesis Testing and Data Analysis}

Hypothesis testing is generally carried out to obtain valid and reliable data analysis results to support the given hypothesis. The calculation and data processing stages comprise coefficient of determination, simultaneous significance test (F-statistics Test), and t-test (T-test score).

\author{
FRAUD $=\alpha+\beta_{1}$ FinSta $+\beta_{2}$ FinTar $+\beta_{3}$ ExPre $+€$ \\ FRAUD: Financial statement fraud \\ $\alpha$ : Constant \\ $\beta$ : Variable coefficient \\ FinaStab: Financial stability \\ Fintar: Financial target \\ Expre: External pressure \\ $€$ : Error
}

\section{RESEARCH RESULTS AND DISCUSSION}

\subsection{Overview of Research Objects}

This study used a sample of manufacturing companies on the IDX for the 2020 period, with a total population of 83 companies. After the selection, the number of samples in this study was 79 companies. 
Table 1. Research Sample of Indonesian Manufacturing

Companies

\begin{tabular}{|l|l|l|}
\hline No & Information & No Companies \\
\hline 1 & Manufacturing Company reporting on the Indonesia Stock Exchange in 2020 & 108 \\
\hline 2 & Manufacturing Company Financial Statements that do not have complete data & 24 \\
\hline Number of companies sampled & 84 \\
\hline \multicolumn{2}{|l|}{ Outlier Data } & 5 \\
\hline \multicolumn{2}{|l|}{ Total Sample Data used } & 79 \\
\hline
\end{tabular}

\subsection{Statistical Test}

\subsubsection{Classic Assumption Test}

Table 2. Normality Test Results

One-Sample Kolmogorov-Smirnov Test

\begin{tabular}{|c|c|c|c|}
\hline & & & $\begin{array}{l}\text { Unstandardiz } \\
\text { ed Residual }\end{array}$ \\
\hline N & & & 79 \\
\hline \multirow[t]{2}{*}{ Normal Parameters ${ }^{a, b}$} & \multicolumn{2}{|l|}{ Mean } & .0170888 \\
\hline & \multicolumn{2}{|l|}{ Std. Deviation } & .12508746 \\
\hline \multirow[t]{3}{*}{ Most Extreme Differences } & \multicolumn{2}{|l|}{ Absolute } & .118 \\
\hline & \multicolumn{2}{|l|}{ Positive } & .118 \\
\hline & \multicolumn{2}{|l|}{ Negative } & -.060 \\
\hline \multicolumn{3}{|l|}{ Test Statistic } & .118 \\
\hline \multicolumn{3}{|l|}{ Asymp. Sig. (2-tailed) } & $.008^{\circ}$ \\
\hline \multirow{3}{*}{$\begin{array}{l}\text { Monte Carlo Sig. (2- } \\
\text { tailed) }\end{array}$} & \multicolumn{2}{|l|}{ Sig. } & $.208^{\mathrm{d}}$ \\
\hline & \multirow[t]{2}{*}{$99 \%$ Confidence Interval } & Lower Bound & .197 \\
\hline & & Upper Bound & .218 \\
\hline
\end{tabular}

a. Test distribution is Normal.

b. Calculated from data.

c. Lilliefors Significance Correction.

d. Based on 10000 sampled tables with starting seed 334431365 .

Table 3. Multicollinearity Test Results

\section{Coefficients $^{\mathrm{a}, \mathrm{b}}$}

\begin{tabular}{ll|l|l}
\multicolumn{2}{c}{ Model } & & \multicolumn{2}{c}{ Collinearity Statistics } \\
Tolerance & \multicolumn{1}{l}{ VIF } \\
\hline \multirow{2}{*}{1} & SQRTAchange & .244 & 4.100 \\
\cline { 2 - 4 } & SQRTLEV & .202 & 4.939 \\
\cline { 2 - 4 } & SQRTROA & .259 & 3.867 \\
\hline
\end{tabular}

a. Dependent Variable: SQRTMgtLaba

b. Linear Regression through the Origin

Table 4. Heteroscedasticity Test Results

\begin{tabular}{|c|c|c|c|c|c|c|}
\hline \multicolumn{7}{|c|}{ Coefficients ${ }^{a, b}$} \\
\hline \multirow[b]{2}{*}{ Model } & & \multicolumn{2}{|c|}{ Unstandardized Coefficients } & \multirow{2}{*}{$\begin{array}{c}\text { Standardized } \\
\text { Coefficients } \\
\text { Beta }\end{array}$} & \multirow[b]{2}{*}{$t$} & \multirow[b]{2}{*}{ Sig. } \\
\hline & & B & Std. Error & & & \\
\hline \multirow[t]{3}{*}{1} & SQRTAchange & .147 & .071 & .350 & 2.060 & .043 \\
\hline & SQRTLEV & .045 & .024 & .359 & 1.924 & .058 \\
\hline & SQRTROA & -.001 & .051 & .003 & .016 & .987 \\
\hline
\end{tabular}

a. Dependent Variable: ResABS

b. Linear Regression through the Origin
Based on Table 2, the normality test results revealed that the value of Asymp. Sig (2-tailed) was 0.208, with a Sig. value $>\alpha 0.05$. Thus, it is concluded that the data of Indonesian manufacturing companies were normally distributed. Then, Table 3 shows that the VIF values for all variables in manufacturing companies were $<10$, and the tolerance values were $>10 \%$. Hence, it can be inferred that the data of manufacturing companies did not experience multicollinearity. Based on Table 4, the heteroscedasticity test results concluded that the financial target and external pressure variables had a Sig. value $>\alpha 0.05$, so the two data variables of this study did not experience heteroscedasticity.

\subsubsection{Hypothesis Testing and Data Analysis}

Table 5. Coefficient of Determination Test Results (R2)

\begin{tabular}{|c|c|c|c|c|}
\hline \multicolumn{5}{|c|}{ Model Summary } \\
\hline Model & $\mathrm{R}$ & R Square & $\begin{array}{c}\text { Adjusted R } \\
\text { Square }\end{array}$ & $\begin{array}{l}\text { Std. Error of } \\
\text { the Estimate }\end{array}$ \\
\hline 1 & $272^{a}$ & .074 & .037 & .112148 \\
\hline
\end{tabular}

Based on Table 5, the value of Adjusted R Square was 0.037. In other words, the independent variables, including financial stability, financial targets, and external pressure, could explain $3.7 \%$ of the dependent variable in the form of financial statement fraud, while the remaining $96.3 \%$ were explained by other factors not included in the research regression model.

Table 6. The Value of F-Test Results

\begin{tabular}{|c|c|c|c|c|c|c|}
\hline \multicolumn{7}{|c|}{ ANOVA $^{a}$} \\
\hline \multicolumn{2}{|l|}{ Model } & $\begin{array}{l}\text { Sum of } \\
\text { Squares }\end{array}$ & df & Mean Square & $\mathrm{F}$ & Sig. \\
\hline \multirow[t]{3}{*}{1} & Regression & .075 & 3 & .025 & 1.990 & $.123^{\mathrm{b}}$ \\
\hline & Residual & .943 & 75 & .013 & & \\
\hline & Total & 1.018 & 78 & & & \\
\hline
\end{tabular}

The F-test results displayed that the Sig. value was 0.123 , so the Sig value was $0.123>0.05$. Thus, the independent variables in the form of financial stability, financial targets, and external pressure together did not affect the dependent variable of financial statement fraud. 
Table 7. Results of Regression Coefficient and Values of T-Test

\begin{tabular}{|c|c|c|c|c|c|c|}
\hline \multicolumn{7}{|c|}{ Coefficients $^{\mathrm{a}}$} \\
\hline \multirow[b]{2}{*}{ Model } & & \multicolumn{2}{|c|}{ Unstandardized Coefficients } & \multirow{2}{*}{$\begin{array}{c}\text { Standardized } \\
\text { Coefficients } \\
\text { Beta }\end{array}$} & \multirow[b]{2}{*}{$\mathrm{t}$} & \multirow[b]{2}{*}{ Sig. } \\
\hline & & B & Std. Error & & & \\
\hline \multirow[t]{4}{*}{1} & (Constant) & .222 & .046 & & 4.886 & .000 \\
\hline & SQRTAchange & .191 & .089 & .249 & 2.141 & .035 \\
\hline & SQRTLEV & -.006 & .043 & -.017 & -.147 & .883 \\
\hline & SQRTROA & -.103 & .063 & -.193 & -1.649 & .103 \\
\hline
\end{tabular}

From the test results above, it can be shown that the constant value was 0.222 , while the regression coefficient $(\beta)$ in each variable: the financial stability variable $\beta_{1}=0.191 ; \beta$ value of financial target variable $\beta_{2}=-0.006$; the external pressure variable $\beta_{3}=-0.103$. Based on the value of the constant and the regression coefficient $(\beta)$ in Table 7 , there was a relationship between the independent variables and the dependent variable using the multiple linear regression model as follows:

FRAUD_SCORE $=0.222+0.191$ Achange +-0.006 Lev - 0.103 ROA + e

The calculation results of each independent variable based on the value of t-test results in Table 7 are that the financial stability variable with a proxy for asset changes had a positive $\beta$ coefficient of 0.191 and a significant value of 0.035 . Hence, the results of this test explain that financial stability had a positive and significant effect on report fraud. Thus, it can be concluded that $\mathrm{H} 1$ was accepted. In addition, the financial target variable had a $\beta$ coefficient of negative 0.06 and a significant value of 0.883 . Therefore, the results of this test explain that the financial target proxy had a negative and insignificant effect on financial statement fraud. Thus, it can be denoted that $\mathrm{H} 2$ was rejected. Besides, the external pressure variable had a $\beta$ coefficient of negative -0.103 and a significant value of 0.103 . Hence, the results of this test explain that the financial target proxy had a negative and insignificant effect on financial statement fraud. Thus, it can be inferred that $\mathrm{H} 3$ was rejected.

\subsection{Discussion}

\subsubsection{The Effect of Financial Stability on Financial Statement Fraud}

Based on the results of testing hypothesis 1, it is known that H1 was accepted. This result indicates that the financial stability variable had a positive influence on financial statement fraud. The relationship between financial stability and financial statement fraud is that if the company's financial condition is stable, the level of corporate fraud will decrease. Vice versa, companies, which experience low financial stability, allow fraudulent financial statements. In this study, financial stability as measured by the number of assets owned by the company was significant in the pandemic year. Here, company stability can be seen from significant asset changes. These results are consistent with research [20], [8], [12], [21] and [22], which found that financial stability affected financial statement fraud. During the COVID-19 crisis, companies that experience financial pressure related to asset stability will tend to commit financial statement fraud. The company will make changes or manipulations in its profits when there is a change in its asset level due to the COVID-19 crisis. This result corroborates the findings [2], proving that the financial stability variable positively and significantly influenced financial statement fraud in a crisis environment due to the COVID-19 pandemic.

Based on agency theory, the management will experience conflict with the principal due to differences in interests if management cannot meet the owner's expectations. It can then put pressure on the management. Consequently, the management will commit fraud to maintain the company's financial stability. In addition, a decrease in total assets or even a negative impact on the company makes investors, creditors, and decision-makers anxious. The condition of the decline is considered unstable, and the company is considered unable to operate properly and is not profitable. On the other hand, when the company's total assets are sufficiently increased and stable, the company is considered capable of providing maximum returns for investors. Thus, managers must account for all their performance to the owner. In order for the manager's performance to look good, the manager manipulates the financial statements to cover the decline in manager performance and increase the company's value. Moreover, during this pandemic, companies are required to survive for quite a long time because the possible impact of this COVID-19 crisis will be long.

\subsubsection{The Effect of Financial Targets on Financial Statement Fraud}

Based on the results of hypothesis testing that has been done, it is known that $\mathrm{H} 2$ was rejected. The result of this test signifies that the financial target variable with ROA proxy had no significant effect on financial statement fraud. It means that although the company's management could not achieve the target according to the expectations of the company owner, it did not experience high pressure so that it did not commit fraudulent financial statements.

In this regard, agency theory states that managers must always have the same financial targets in the previous year to maximize firm value. These conditions make the management act in any way in the interests of the principal. Likewise, the conditions during this pandemic have resulted in financial pressure related to targets for management. Also, principals still demand management to achieve financial targets during the pandemic, before and after. In 
this case, financial targets show how well the company's performance generates profits by utilizing its assets. On the contrary, poor company performance can experience conflict with internal and external parties.

This study's analysis results conclude that the company's financial targets in this pandemic environment are extraordinary, so this is beyond the limits of management's ability. Hence, it did not put pressure in the form of financial targets to always achieve financial goals. Besides, company management would not always be encouraged always to improve the best performance to achieve financial targets.

\subsubsection{The Effect of External Pressure on Financial Statement Fraud}

The t-statistical output results indicate that the external pressure variable had no significant effect on the financial statement fraud variable since the t-statistic value was greater than the t-table. In this study, pressure from external parties did not affect the level of fraud. The pressure that often occurs from outside parties is the need to obtain additional debt or external sources of financing to remain competitive, including research financing and development or capital expenditures. Thus, it can be concluded that outside parties are aware of the extraordinary economic uncertainty environment from the COVID-19 pandemic so that management is not under so much pressure to meet the financing to make the company's performance look good. Most likely, pressure from external parties from the government encourages external business actors to provide relaxation for companies experiencing the impact of the financial crisis due to COVID-19. This result is consistent with research [14] that the external pressure variable proxied by leverage did not significantly affect financial statement fraud.

\section{CONCLUSION, SUGGESTION, AND LIMITATION}

\subsection{Conclusion}

The conclusions of this study are first, during the COVID19 pandemic, financial stability, which was proxied by the ratio of changes in total assets, had a significant effect on financial statement fraud. It signifies that the increase in the ratio of changes in total assets becomes pressure in carrying out financial statement fraud. Second, in the financial crisis environment due to COVID-19, the financial target proxied by ROA did not significantly affect financial statement fraud. It demonstrates that the achievement of ROA is not a financial pressure for management in conducting financial statement fraud during this coronavirus crisis. Third, external pressure in this study that used the company's leverage proxy had no significant effect on financial statement fraud. It illustrates that the increase in funding from external parties is not a pressure for management to commit financial statement fraud. The higher the leverage ratio in a company will not be a factor causing management to commit financial statement fraud.

\subsection{Research Suggestion and Limitation}

From the research results that have been carried out, the suggestions given for further research are as follows. First, further researchers are expected to add samples of companies from other sectors, such as the service sector, banking, etc. Second, the observation period should be extended so that the observations made can predict the long term. Third, further researchers are expected to use other measuring tools so that they get more valid results. However, this study has limitations. First, the researcher only used a research period of one year, namely 2020, so it did not provide long-term predictions. Second, the data used in this study employed secondary data so that the research conducted gave invalid results to detect fraud. Third, the researcher only utilized the financial pressure factor in examining the occurrence of fraud in the company. One factor alone is not enough to prove the level of fraud that exists within the company.

\section{REFERENCES}

[1] Center for Accounting Studies Unpad. (2020). Dampak Pandemi Corona Terhadap Laporan Keuangan dan Praktik Bisnis di Indonesia. Retrieved July 6, 2021, from FEB Unpad website: https://feb.unpad.ac.id/dampak-pandemi-coronaterhadap-laporan-keuangan-dan-praktik-bisnis-diindonesia/

[2] Marviana, R. D., \& Amalia, M. M. (2021). Pendeteksian Fraud Laporan Keuangan Perusahaan Perbankan Dalam Masa Pandemi COVID-19. Jurnal Stie Semarang, 13(2), 32-54.

[3] ACFE. (2016). Report To The Nations On Occupational Fraud and Abuse 2016. In Global Fraud Study.

[4] Spathis, C. T. (2002). Detecting false financial statements using published data: some evidence from Greece. Managerial Auditing Journal, 17(4), 179-191. https://doi.org/10.1108/0268690021042432

[5] Tuanakotta, T. M. (2013). Mendeteksi Manipulasi Laporan Keuangan. Jakarta: Salemba Empat.

[6] Tuanakotta, T. M. (2010). Akuntansi Forensik dan Audit Investigasi (2nd ed.). Jakarta: Salemba Empat.

[7] Indonesia ACFE. (2018). Survei Fraud Indonesia 2016. In ACFE, Indonesia Chapter. https://doi.org/10.1201/9781315178141-3

[8] Skousen, C. J., Smith, K. R., \& Wright, C. J. (2009). Detecting and predicting financial statement fraud: The effectiveness of the fraud triangle and SAS No. 
99. Advances in Financial Economics, 13, 53-81. https://doi.org/10.1108/S15693732(2009)000001300

[9] Niesche, C. (2020). How coronavirus heightens the risk of fraud. Retrieved July 7, 2021, from Acuity website: www.acuitymag.com/finance/howcoronavirus-heightens-the-risk-of-fraud

[10] ACFE. (2008). 2008 Report to the Nation on Occupational Fraud \& Abuse.

[11] Dorris, B. (2021). Coronavirus Pandemic Is a Perfect Storm for Fraud. Retrieved July 7, 2021, from ACFE website: https://www.acfe.com/pressrelease. .aspx ?id $=4295010491$

[12] Utama, I. G. P. O. S., Ramantha, I. W., \& Badera, I. D. N. (2018). Analisis Faktor-Faktor Dalam Perspektif Fraud Triangle Sebagai Prediktor Fraudulent Financial Reporting. E-Jurnal Ekonomi Dan Bisnis Universitas Udayana, 1, 251. https://doi.org/10.24843/eeb.2018.v07.i01.p09

[13] Sabat Adrian Kayoi, F. (2019). Faktor-Faktor Yang Mempengaruhi Financial Statement Fraud Ditinjau Dari Fraud Triangle Pada Perusahaan Manufaktur Di Bursa Efek Indonesia Periode 2015-2017. Diponegoro Journal of Accounting, 8(4), 1-13.

[14] Setiawati, E., \& Baningrum, R. M. (2018). Deteksi Fraudulent Financial Reporting Menggunakan Analisis Fraud Pentagon: Studi Kasus Pada Perusahaan Manufaktur Yang Listed Di Bei Tahun 2014-2016. Riset Akuntansi Dan Keuangan Indonesia, $\quad 3(2), \quad 91-106$. https://doi.org/10.23917/reaksi.v3i2.6645

[15] Cressey, D. R. (1953). Other People's Money A Study in the Social Psychology of Embezzlement.

[16] Albrecht, W. S., Albrecht, C. C., Albrecht, C. O., \& Zimbelman, M. (2009). Fraud Examination. In South Western-Cengage (Third). South Western Cengage Learning.

[17] Zimbelman, M. F., Albercht, C. C., Albercht, W. S., \& Albercht, C. O. (2014). Akuntansi Forensik (Forensic Accounting). In Salemba Empat (Vol. 4). Jakarta: Indonesia Salemba Empat.

[18] Arens, A. A., and J. K Loebbecke., and J. (2003). Auditing Pendekatan Terpadu. Alih Bahasa. Jakarta: Salemba Empat.

[19] Wells, J. T. (2014). Principles of Fraud Examination (4th ed.). Principles of Fraud Examination: Principles of Fraud Examination.

[20] Sihombing, K. S., \& Rahardjo, S. N. (2014). Analisis Fraud Diamond Dalam Mendeteksi Financial Statement Fraud: Studi Empiris Pada Perusahaan Manufaktur Yang Terdaftar Di Bursa Efek Indonesia (Bei) Tahun 2010-2012. Diponegoro Journal of Accounting, 03(2). https://doi.org/10.25105/semnas.v0i0.5780

[21] Mariana, M., \& Hakim, L. (2016). Pendeteksian Pemanipulasian Laba: Pengujian Teori Fraud Triangle dan Dampak Pengadopsian International Financial Reporting Standard ( IFRS ). Simposium Nasional Akuntansi XIX, Lampung, 1-30.

[22] Sasongko, N., Nurmulina, A., \& Fernandez, D. (2019). Analysis of Fraud Factors in Financial Statement Fraud. The Journal of Social Sciences Research, 5(4), 918-923. https://doi.org/10.32861/jssr.54.918.923

[23] Situngkir, N. C., \& Triyanto, D. N. (2020). Detecting Fraudulent Financial Reporting Using Fraud Score Model and Fraud Pentagon Theory: Empirical Study of Companies Listed in the LQ 45 Index. The Indonesian Journal of Accounting Research, 23(03), 373-410. https://doi.org/10.33312/ijar.486

[24] Hapsari, Asri Dita. 2014. Pendeteksian Tingkat Fraud melalui Faktor Risiko, Tekanan, dan Peluang (Studi Kasus pada Perusahaan Perbankan periode 2010 - 2012). Naskah Publikasi Ilmiah. Universitas Muhammadiyah Surakarta

[25] Rusmana, O., \& Tanjung, H. (2019). Identifikasi Kecurangan Laporan Keuangan Dengan Fraud Pentagon Studi Empiris Bumn Terdaftar Di Bursa Efek Indonesia. Jurnal Ekonomi, Bisnis, Dan Akuntansi, 21(4). https://doi.org/10.32424/jeba.v21i4.1545

[26] Yesiariani, M., \& Rahayu, I. (2016). Analisis Fraud Diamond Dalam Mendeteksi Financial Statement Fraud ( Studi Empiris pada Perusahaan LQ-45 yang Terdaftar di Bursa Efek Indonesia Tahun 2010 2014 ). Jurnal SNA XIX, 1-22.

[27] Healy, P. M., \& Wahlen, J. M. (1999). A review of the earnings management literature and its implications for standard setting. Accounting Horizons, $\quad$ 13(4), 365-383. https://doi.org/10.2308/acch.1999.13.4.365

[28] Scott, W. R. (2009). Financial Accounting Theory (5th Editio). https://doi.org/10.4324/9780203968147.sec6 